\title{
SYSTEMIC DEGRADATION OF WORK IN HYDRO-AGRICULTURAL BUSINESS
}

(a) Phd. in Geography, State University São Paulo Julio de Mesquita Filho, Presidente Prudente (UNESP/PP). http://lattes.cnpq.br/1283115540482082

\section{(*) CORRESPONDING AUTHOR}

Address:-UNESP/PP - Rua Roberto Simonsen, 305, CEP: 19060900, Presidente Prudente (SP), Brasil. tEL: + (+55 18) 32295375

E-mail: thomazjr@gmail.com

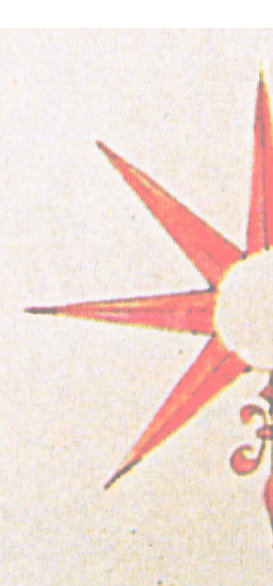

\begin{abstract}
We have used the concept of hydro-agricultural business in our studies, since we understand that capital, when searching for flat, fertile lands with favorable logistics, also requires water availability and expropriates traditional and native peasant populations. Thus, whether superficial or from aquifers, water is at the center of territorial disputes and conflicts. It is necessary to add, that in this route of exclusion the systemic degradation of workers and of the natural and transformed environments has intensified. That is, the differentiated advantages for the monoculture / latifundial / agricultural-exporting project, which has heavily penalized and condemned millions of workers to exclusion and expulsion from the land, and the population in general to diseases, chronic risks of contamination and pure and simple discarding. These consolidate themselves in the name of the modernization of production processes, as evidenced by the research in which many of us are involved. Learning about these processes and their effects requires care and attention to specific occurrences and procedures to address them. This may be a new phase of social exclusion, in the context of the systemic degradation of labor in hydro-agricultural business.
\end{abstract}

Keywords: Systemic degradation; Labor; Hydro-agricultural business; Working class; Health-disease.

\section{RESUMO/RESUMEN}

\section{DEGRADAÇÃO SISTÊMICA DO TRABALHO NO AGROHIDRONEGÓCIO}

Utilizado o conceito de agrohidronegócio nos nossos estudos, por entendermos que o capital, quando busca terras planas, férteis, com logística favorável, também requer disponibilidade hídrica e expropria populações camponesas, tradicionais e originárias. Assim, seja superficial, seja de aquíferos, a água está no centro das disputas e conflitos territoriais. É necessário acrescentar, nessa rota de exclusão, que a degradação sistêmica dos trabalhadores, dos ambientes naturais e transformados tem se intensificado. Isto é, as vantagens diferenciadas para o projeto monocultor/latifundista/agroexportador, que tanto tem penalizado e condenado milhões de trabalhadores à exclusão, à desterreação, e a população em geral, às doenças, aos riscos crônicos das contaminações, ao descarte pura e simplesmente, se consolidam em nome da quimificação dos processos de produção modernos, como se constata por meio das pesquisas em que muitos de nós estamos envolvidos. Apreender esses processos e seus efeitos exigiu cuidados e atenções para com as ocorrências e procedimentos específicos para abordá-las. Essa pode ser uma nova fase da exclusão social, no ambiente da degradação sistêmica do trabalho no agrohidronegócio.

Palavras-chave: Degradação sistêmica; Trabalho. Agrohidronegócio; Classe trabalhadora; Saúde-Doença.

\section{DEGRADACION SISTÉMICA DEL TRABAJO EN EL AGROHIDRONEGOCIO}

Hemos utilizado el concepto de agrohidronegócio en nuestros estudios, porque creemos que el capital cuando busca un terreno llano y fértil, con la logística favorables etc., expropia poblaciones originales. Por lo tanto, sea superficial, sea de los acuíferos, el agua está en el centro de las controversias y los conflictos territoriales. Debe agregar a la ruta de exclusión que la degradación sistémica de los trabajadores, los entornos naturales y transformados se han intensificado. Es decir, las distintas ventajas para el proyecto de monocultivo/latifundista/exportación de productos agrícolas, que ha penalizado y condenado a la exclusión millón de trabajadores, a la desterreação, y la población en general a las enfermedades crónicas, los riesgos de contaminación, se consolida en nombre de la quimificação de los procesos de producción modernos, como puede se constata a través de la investigación que muchos de nosotros estamos involucrados. Esto puede ser una nueva fase de la exclusión social en el ambiente de la degradación sistémica del trabajo en agrohidronegócio.

Palabras clave: Degradación Sistémica.; Trabajo. Agrohidronegócio; Clase trabajadora; Salud-Enfermedad.: 


\section{INTRODUCTION}

The convergence of research efforts, aiming to articulate the struggle for access to land (flat, fertile, cheap and with compatible logistics) and water (surface and underground), in addition to the management of water resources, has enabled us to approach the monopolization of land - with the maintenance / intensification of the latifundial trajectory - and the degradation of the environment and labor, within what we call ${ }^{1}$ the hydro-agricultural business in Brazil, as an expression of the Brazilian agricultural export model and its intrinsic destructive hallmark. Thus, for example, when we address the cultivation of soybeans, sugarcane, eucalyptus, and maize, fruit monoculture and meat processing, we are immersed in the degraded environment of the model concentrating land, water, income, and wealth. It is also the protagonist of the destruction of the productive forces and multiplier of the misery and poverty of the workers.

Nonetheless, under the umbrella of the hydro-agricultural business, of large oligopolistic / monopolistic structures, there is a complex range of occurrences: the growth of social and gender inequalities; ethnic-racial persecution / extermination, and conflicts over land / water (THOMAZ JUNIOR, 2013a). Also, the intensification of the exploitation of labor and its current attributes of destruction of the productive forces, be it by unemployment / underemployment or by discarding; environmental degradation (of water sources, mineral provinces, soils, etc.); the repression and criminalization of social movements; the control of corrupt sectors of justice and labor tribunals, as well as the appellations and higher instances, such as the Supreme Labor Tribunal (TST) and the Supreme Court (STF). These, then, are said to have imposed undemocratic and authoritarian indelible marks against workers, disrespecting the right to strike, destroying productive forces, discarding workers from the labor market. They act against peasants and indigenous and traditional communities, denying them, respectively, the right to access to occupied and non-social land and to agrarian reform, as well as to those parts of the territory already set aside and demarcated as indigenous lands / reserves, in the 1988 Constitution, etc. Synthetically, these are the structuring components of the civilization of barbarism (THOMAZ JUNIOR, 2007) of the society of capital that aggregates and qualifies the endemic brand of systemic degradation. In the emblem of the hydro-agricultural business, these attributes and corollaries of the contradictory and destructive development of social forces and the nature of their respective historical times constantly redefine the territorial arrangements of spaces. (SMITH, 1988).

This coexistence between the modern and the degraded, which, in the name of development, presents itself as sustainable, carries within itself the germ of destruction and the signs of poverty, especially after the consolidation of the innovations of the chemicalizing brand that spreads in the environment of large-scale monoculture production for export, which broadens and intensifies the contamination of the workers directly involved, as well as frontier communities, consumers, water sources, the air, the soil, fauna, flora, etc. (THOMAZ JUNIOR, 2014). This commoditization as a practice for the production and construction of the agricultural-chemical-food productive chains, in addition to affecting food production (rice, beans, vegetables and fruits for human consumption) (THOMAZ JUNIOR, 2013c), relies on the support of the public resources and logistics required to crown this monopolistic model of success. As a rule, it disregards agreements and labor contracts, labor laws, regulatory norms and imposes itself as the protagonist of the systemic degradation of labor.

In a timely manner, we can reinforce the impact of the forms of exploitation of the labor force, implemented by contemporary capitalism, as Harvey (2013) ponders, when analyzing the forms of accumulation - with reference to K. Marx and R. Luxemburg - through the concept of accumulation

(1) Initially, this concept was coined by Mendonça and Mesquita (2007), in the text "The Hydro-agricultural business in Cerrado Goiano: Construction of $(\mathrm{Re})$ existences". Following our research, we broaden the meanings and contents of the material existence of the social processes that give identity to the concept of Hydro-agricultural business. See: Thomaz Junior (2009); (2010); (2015); Thomaz Junior Et al. (2012). 
by spoliation. Indeed, at the moment of the globalization of capital, the mechanisms and procedures used at the moment of original or primitive accumulation are not absent, as something exclusive and unique, corresponding to the initial phase of capitalism, which has disappeared, over time. It is worth emphasizing that Luxemburg's criticism of Marx having relegated primitive accumulation to the past was based on the simultaneous and always conflictual existence between the social strata and non-capitalist societies. Therefore, these are driven by the natural economy, but subsumed and indispensable to the survival of the system itself. Luxembourg (1970) explains that the problem consists precisely in the fact that, "in reality, there has never been - and is not - a self-sufficient capitalist society in which capitalist production dominates exclusively" (p. 298).

On the uplifting basis of this development project based on the production of surplus, the exploitation of unpaid labor and the appropriation of surplus value, modifications are required in the metabolic process of the system of capital for it to remain hegemonic in bourgeois society. Thus, changes in technological levels, forms of management and control of labor are implemented, but the historical requirements of the State are maintained in the service of this enterprise. It is for this reason and not fortuitously that the bourgeois state is, in fact, the protagonist of the social structure of political, social, economic, repressive, military command of the social metabolism of capital and is required to ensure the feasibility of the continuity of the characteristic production system. As Mészáros (2015) states in The Mountain We Must Conquer - a work that emphasizes the dissolution of the bourgeois state into a social order emancipated from capital: "The structural crisis of our time demands an ever more direct involvement of the State in the direct survival of the system" (p.27). There are no positive teachings to be drawn from this experience, or as Mészáros (2002) tells us, there is no possibility of positivity through the supposed creative destruction, that is, as if the destruction of nature in the name of creating goods could develop productive forces, with the purpose of improving the material, living and working conditions of the working class. (ROMERO, TIRADO, 2016).

Continuing this introductory synthesis, it is opportune to recall that the true purpose of capitalist production is not surplus-value in a restricted way, but the gamble on the endlessness of this process and in quantities that multiply themselves. For this, the complex relationship of domination and the control of capital over labor are mixed, in the growing and increasingly wide subordination of the value of use to the exchange value and the market, which implies a reduction in the rate of utilization of goods and, consequently, the inordinate capacity to produce, without a compatible proportion of consumption, resulting in waste, unbridled consumerism, the degradation of the environment and labor, with particular attention to the hydro-agricultural business.

Another important aspect, according to the main founding axes of the hydro-agricultural business, which is the basis for understanding the systemic degradation of labor and which reveals the signs of synchronization of this process on a global scale, is that the traditional export-oriented livestock farming in Brazil is subject to the commands of the internationalized processes of the productive restructuring of capital, which subordinate the agricultural-industrial circuit as a whole, in the production, circulation, distribution and consumption of agricultural commodities, of chemical-biological-mechanical-informational inputs. This network of relationships makes the scales of dependence and domination even more complex, because it is sustained and redefined, to a great extent, guided by the reference points of the transnational conglomerates and trusts, fixed in the financial sphere or in fictitious capital and the strategies and interests of the manipulative system (THOMAZ JUNIOR, 2015).

The unfolding of this process for labor, from the instability of jobs, technological unemployment, more rigid forms of control, exposure to risks and diseases that evidence the emphasis on the intensification of exploitation, the withdrawal of rights through reforms of legislation (both of the Constitution and the negotiation and protection codes), such as in Brazil, especially after the 2016 coup (BOITO JUNIOR, 2017). The habitual noncompliance, the effects of the chemicalization of the 
productive processes in the specific cases of the agricultural processing chains and the plundering of natural resources point to chronic insolubility (MÉSZÁROS, 2015) linked to the uncontrollability of capital, a finished expression of the destructiveness of this mode of production. However, it is important and opportune to add to this list of regressions and inequalities intrinsic to the societal metabolism of capital, the most unconsidered setbacks, which rebound in class subjectivity, or in the political organization of the workers (trade unions, trade union federations, associations, cooperatives, and social movements) that influence all spheres of life of the working being. Here we include daily life, intolerance, the rise of cases of xenophobia, racism, homophobia, whose examples respond on a global scale, no longer restricted to the grotesque, well-known Western pattern, as in the cases of Latin America and Africa, and especially the specific perversity of the working processes in China, with the alarming cases of suicide in the workplace (ANTUNES, 2016), which swell the civilization of barbarism (THOMAZ JUNIOR, 2007) of capital to exhaustion. In this regard, it is worth recording the cinematographic production that widely portrays the new / old structures of labor control with multiple meanings, which are partially or totally remade to meet the new objectives of capital accumulation in the twenty-first century, such as: Inside Job (2010), by Charles Ferguson; Mondays in the Sun (2004), by Fernando Leon; Pride (2014), by Mathew Marcus; On Modern Servitude (2010), by Jean François Brient; Clouds of Venom (2013), Beto Novaes etc.

This process is a constituent part of the reorganization of capital at the global level, and the marked changes that have taken place in the productive environment make the scenario that will materialize in a new spatial order shaped by the flexible company flourish, which brings with it new regulations regarding mechanisms and patterns of accumulation and value generation. Hence the identification of the systemic degradation of labor in the hydro-agricultural business, as a reference for our reflections in this article. The contradictory movement between regressive (as to the impacts on labor) and spectral (that express the modernity of the technological development) forms of the social metabolism imposed on our research, focused on the object of the worker's living and working conditions and their struggles of resistance and emancipation.

Thus, the manual trait of Taylorism, as opposed to management work (intellectual), gives way to the new brand of precariousness, now mediated by control mechanisms which propose to soften the Taylorism-Fordism divide. Thus, the work environment is more participatory, technical / automated, as well as seemingly less divided, but still governed by the principles of the systemic degradation of work. (BIHR, 1998).

In this sense, the predominant regressiveness in an environment ideologically marked by spectral innovations has, in the degradation of labor, the attestation of the systemic irrationality of the capitalist mode of production. If we consider three contemporary technical / technological moments, such as mechanical, electromechanical and computer-microelectronic automation, it is evident that the invisibility of the processes of domination and control by the bourgeois sectors that hegemonize the concentration and monopolization of capital, cloud the expedients used to maintain the levels of extraction of surplus value and the control of labor.

Thus, interspersed with the new decisions about productive organization, such as outsourcing, the artifices of labor exploitation, with the resumption of subtle devices that practice relative surplus value, through the intensification of labor, and absolute surplus value (with the extension of the working day) in a markedly more technical and informational world, there is the Cybertariat (HUWS, 2004), notably affirmed, without, however, being concerned with the worker's health or living conditions. (RIBEIRO, 2015). 


\section{CRITICISM OF THE DESTRUCTIVE ENVIRONMENT OF THE HYDRO-AGRICULTURAL BUSINESS}

The harmfulness of this process, the reformed environments and the combined formulations of work routines result in occupational diseases, which cover numerous situations of exposure to hazards, mutilation, contamination, poisoning, serious accidents, disposal and even deaths.

These subjects are increasingly part of our research. There are significant examples of territorial and class disputes in Brazil in the twenty-first century, not yet visible to the majority of society, overshadowed by capital's million-dollar marketing campaigns and / or in tune with systemic irrationality and the destructive design of agricultural development based on the model of large monoculture areas for export, based on the increasing consumption of agrochemicals (RIGOTTO, 2011), to the detriment of the production of food for human consumption, in small family units, referenced in agroecology.

Immediately, the question arises regarding the nature of the economic and social crisis present in the twenty-first century, which can no longer be denied. However, it is necessary to emphasize that the crisis that we face is structural, deep and, at each moment, becoming more serious, with a global amplitude, and as Mészáros (2011) indicates "takes the form of an endemic, cumulative, chronic and permanent crisis" (p.11-12). That is, it affects the totality of a social complex, in all its relationships with its constituent parts, in the same way as with other complexes (BOMBARDI, 2011). The roadmap of a financial crisis that triggered the global crisis began at the end of July 2007, thus constituting a crisis of the predominantly financially accumulated regime, which began in the late 1980s. Chesnais (2011, p. 186) goes deeper when he ponders that this enormous crisis "[...] is the connection between the economic and financial crisis and the global ecological crisis in its different dimensions."

The articulation between the crisis of the pattern of global accumulation, its financial dimension and the deepening of its structural dimension imposed the productive restructuring of capital, starting from the 1970s, which spatialized itself from a new technical, now informational basis. In this process, it was necessary to destroy the relationships established between capital, labor and the State; and the Welfare State after the Second World War. The solution to the crisis was cemented by neoliberalism, that consolidated the bourgeois intent of social control. The fight against inflation, privatization and the dismantling of the state made up the recipe for the safeguarding of capital accumulation and the apparatus of the decadent bourgeoisie. It is important to recall Antunes (1999) when he asserts that the nexuses between neoliberalism and capital accumulation joined to guarantee the structure of the development of the techniques announced with Toyotism.

It is in this environment of intense changes and the increasing destruction of the productive forces that the intensification of the role of large transnational corporations took place through inter-capitalist competition, which, at the same time, enjoy, on the one hand, the public policies implemented by the State that shape the expansion of hydro-agricultural business and the consequent territorial disputes in Brazil, and, on the other hand, make labor even more precarious. Even worse, it is not restricted to this sector of activity, since with increasing doses of the loss of rights, reified and intensified by the illegitimate, unelected Temer government, which counting on valuable protection from the mainstream media, the cowardly and glittering support of sectors of the Federal Public Prosecutor's Office, the Supreme Federal Tribunal and with the swill of the National Congress, has not tired of imposing, in less than 12 months of misrule, through practices of corruption / coercion, which, in unison, use reinvented frauds, maneuvers of all kinds and flim-flam; a new order of destruction.

These specific marks of the periphery of the system, whose elite is subservient to big capital, plus the founding strategies of the coup of August 2016, which destroy social achievements, eliminate workers' political leadership, criminalize social movements, deny rights and along with the 
state apparatus consolidate the bases of the typical barbarism that marks this escalation, imposing the foundational references of the systemic degradation of labor.

The devastating picture of climate, society and labor is in tune with the ideology of development, mistakenly labeled as sustainable, and at the dawn of the twenty-first century, it reinforces its efforts to increase world poverty or to impoverish workers, including those who are employed. In other words, this general process is reinforced by the millions of unemployed and those rejected from the labor market, just like the extreme destruction of nature and ecosystems, which deny the false scope of sustainable actions and the humanization of capitalism, driven by million-dollar, mendacious media campaigns, all ably respected and defended by various sectors of society, that also rebound in universities.

This reveals that society in general and workers in particular are subsumed by the instruments of control and domination of capital cleverly manipulated by the different sectors of the bourgeoisie ensconced in control of the state. If such systemic destructive fury were not enough, capital and its various branches transfer responsibilities to the workers or blame them, including for unemployment, by naturalizing the disastrous effects of structural crises. At the very least, it is noteworthy that in the period of the neo-developmental pact established in Brazil between 2003 and 2010, during the two Lula administrations, the few advances achieved have come to nothing because national bourgeois factions and their articulations at the international level felt threatened in their superior enterprise of the accumulation of capital associated with social control. This is the reason for the architecture of the parliamentary-juridical-mediatic coup, which in the short term promoted the destruction of hitherto unknown social achievements, which reached a significant number of employees and workers in general. The arrangements carried out within the power bloc of sectors of the national bourgeoisie, associated with the lower middle class, parts of the urban proletariat, the peasantry, in the post-neoliberal field of play, despite representing a proposal of income redistribution in the wider neoliberalism, wrote in the recent history of Brazil. At this time, the minimum salary was increased, the Zero Hunger program, the Food Acquisition Program (PAA), Minha Casa Minha Vida, and Luz para Todos were created. Tax exemption was granted to sectors of the national industry to promote the domestic consumption of household appliances, Federal Universities were created and there were substantial increases in the National Network of Vocational Public Education. The banks and monopolized groups of the hydro-agricultural business had never made so much profit so quickly.

The restoration of neoliberalism, via the juridical-parliamentary-media coup d'état, on 08/31/2016, through which Michel Temer ascended to the presidency of the Republic, wrecked the timid popular project that had not taken off properly, which despite the flashes and crumbs of improvements was baptized as neo-developmental. It was denied by the bourgeois fractions no longer attuned to Lullism (SINGER, 2014, ALVES, 2014, PERU, 2016, BOITO JUNIOR, 2017). The new interests of the bourgeoisie with an emphasis on state power in Brazil and the alliance with sectors of workers' organizations and national business focused on the interests of the international financial and rentier bourgeoisie aligned with the USA, have in the coup the guarantees for the imposition of the ultra-liberal reforms needed to remove the rights and protections of workers from the text of the constitution. Boito Junior (2017), reinforces that it is central to the execution / accomplishment of the coup d'état to promote the reduction of the State through the PEC 55, to make labor legislation more flexible and intensify it through the institution of total outsourcing, to increase the absolute added value with Social Security reform, syndicated to the dismantling of the public machine, etc.

It is through these contradictions that the new fields of class disputes and conflicts occur, as well as references of the resistance struggles that we are pursuing in our research, in order to return to the necessary understanding of labor, as a founding category for the understanding of spatial structure, territorial dynamics or geographical space. Thus, the totality of labor is constituted in the theoretical-political-ideological construction of the geographic dynamics of emancipatory struggles and class conflicts. 
This means that, under capitalism, labor as a vital activity is seen as estranged labor, the designative expression of a social relationship surmounted by private property, capital, money, and social control. Antunes' (2013) argument that "to say that with the validity of the world of the commodity in its spectral objectivity, estrangement, which is totally unnatural, becomes a decisive social phenomenon for modernity and overcoming it", challenging the continuity of our research. As we know that Antunes ' comments (2013, p. 37) endorse the approval of Lukacs' rich contribution ${ }^{2}$ to the critical debate on the structures of the foundation and domination of the society of capital, which through Marx's materialist ontology restates the question of logic founded in the object, in the unraveling of the decisive categories of the social being, where labor, even when it conforms itself with alienated labor, does not eliminate its dimension of a vital activity.

Based on these assumptions, we can consider that, in spite of the specificities of the sugarcane and wood-cellulosic agricultural-industrial segment, in relation to the many other forms of expression of capital, in term of dynamics, reproductive strategies, labor control and the gamble of its constant precarization / fragilization, there are similarities. Since the original formulation by Marini (2008), the concept of super-exploration of labor vitalizes the current meanings of the relationship between labor and illness, whether in the cutting of sugarcane or in the eucalyptus cultivation operations, etc. ${ }^{3}$

\section{SCARS OF THE CRUELTY OF THE SOCIAL STRUCTURE OF CAPITAL ON THE BODY AND SOUL OF THE WORKER}

The intensity, breadth, and harmfulness of labor processes attuned to the imposed pattern of accumulation and the commodification of the labor force allow us to propose that lesions, illnesses and scars are not restricted to physical marks but also reach the worker's soul due to the symptoms of exclusion, and rejection, as well as by the inability to continue to sell the workforce or, furthermore, due to the evils that are confined to the scope of labor madness (DEJOURS, 2015). That is, capital appropriates today the future years of the worker, or the force required for the act of labor, through the mechanisms of intensification, the extension of working times or procedures that characterize the super-exploitation of labor (VERÇOZA; MORAES SILVA, 2016).

In twenty-first century England, there has been a notorious erosion of the Welfare State, with workers with a zero-hour contract, that is, they are not guaranteed a minimum work load and are paid only on the basis of hours worked (JONES, 2016). A similar case occurs in Japan, with the difference that workers have to be at the disposal of the company, despite not having any guarantee of a daily payment.

Regarding the rural worker, in addition to currently known cases, the plight of independent workers is noteworthy, since their existence is a direct result of contracting and payment procedures that directly violate NR-31, the CLT and the 1988 Constitution itself. These workers are at the fore of atrocities committed by capital, as unlike the migrant farm workers or the non-resident daily worker, they are not beneficiaries of an employment contract and have no guaranteed rights. They only exist on the outskirts of the job market because they undertake to remain faithful to the middlemen (known as cats), not revealing the violation of their rights carried out by capital to third parties. There is a tacit agreement among the workers themselves, the foundation of an imposed and consented silence, but controlled by the inspectors and / or "cats", who forbid publicizing the reality of this marginal labor, sustained by the high volatility of the activities carried out. That is, each day brings different places and activities, dealing with products and processes in different jobs, such as: stone harvesting in sugarcane plantations, picking oranges, harvesting coffee, sweet potatoes, and grass seeds etc. This issue refers us to specific studies that are already underway,

(2) Reviews for "The Ontology of Social Being II"; Op. Cit.

(3) On the risks and harm of work in the large eucalyptus monoculture areas of contemporary Brazil, see the work of Perpetua and Thomaz Junior (2015), and Perpetua (2016). However, Silva (2006) has already pointed to the need for specific studies aimed at the quality of life and work of the workers involved in the manual cutting of sugarcane. 
however, it signals that denying rural workers their guaranteed minimum rights, plus the volatility of different tasks that require different performances and are referenced to levels of specific productivity and efficiency, will most likely reserve these workers of endless drudgery, multiple illnesses, the consequences of occupational accidents, without legal protection or cover from the actions of the trade unions. (Silva, 2005).

However, it is inside the frequently degrading expressions of labor and (territorial) conflicts that we find the thread of the actions of the subjects involved in the environment of reproduction of capital in the hydro-agricultural business in Brazil. As a result, the actions that place workers against capital, the inter-capital cracks revealed by the need for flat, fertile land with available water suitable for mechanization and the expansion of the technological package for export - and among the workers themselves are, par excellence, examples of disputes over territory that reveal the content and meanings of the expansionist and concentrating process of the hydro-agricultural businesses in general.

This process of expansion of the hydro-agricultural business, which is consolidated in practically all Brazilian biomes, is strengthened with intensity in the Cerrado, the Atlantic Forest, the Amazon and in some areas of the semi-arid Northeast. The most recent, the MATOPIBA (a quadrilateral composed by the states of Maranhão, Tocantins, Piauí and Bahia), is the last frontier of the hydro-agricultural business. This agricultural export enterprise conciliates interests of agrochemical-food-financial conglomerates, giving rise to production for export (commodities), such as soybeans, corn, cotton, eucalyptus, fruit, fattening livestock on large tracts of land, factory farming (pigs, chickens), industrial fishing and fish farming. Currently, it is also associated, directly or in a consortium with other economic groups, to the construction of dams and hydroelectric dams (ALVES, 2014).

Thus, deforestation, the expansion of cultivars and commodities based on destructive chemicalization of transgenic seeds, as common practice to produce goods coming from the commoditization of agriculture and livestock. Just to give an idea of the scale of this destructive process, in Brazil, between 2007 and 2013, the volume of agrochemicals consumed on cultivated land doubled, while cultivated areas increased by less than a third. (THOMAZ JUNIOR, 2014a). This process may be better situated when we consider the increase in the average consumption of agrochemicals in relation to the planted areas, that is, it rose from 10.5 liters / ha in 2002 to 13 liters / ha in 2013. Mato Grosso led the way, representing $20 \%$ of national consumption, followed by São Paulo, 14.5\%, and Paraná, $14.3 \%$. This leap is associated with several factors, starting with the expansion of planting transgenic soybeans, which have a higher consumption of glyphosate, as well as the increase in the resistance of weeds, insects, fungi and other predators. In addition, there was an increase of crop diseases, such as Asian rust in soybeans, which requires a greater consumption of agrochemicals.

According to the ABRASCO Dossier (CARNEIRO Et al., 2015), 70\% of the food in natura consumed in Brazil is contaminated by pesticides. So, $28 \%$ of the cases diagnosed, contain unauthorized substances. Taking into account the total 440 active ingredients and 2,400 pesticide formulations, of the 50 most used on crops in Brazil, 23 are banned in the European Union, such as glyphosate, endosulfan, metamidephos, 2,4D, parathion-methyl etc. This is without counting the foods that go through agroindustrial processing, usually produced from genetically modified seeds, which also contain elements and particles harmful to health. Taking into account this simultaneous set of situations, Castilho (2016) indicates that despite notorious underreporting, in 2013 there was the highest number of notifications of pesticide intoxications in the country since the beginning of the historical series; a total of 12,534 cases.

It is important to note that, despite variations regarding the amount of agrochemicals (pesticides and fertilizers) applied per crop, ${ }^{4}$ as well as product categories, ${ }^{5}$ especially in monocultures

(4) In this respect, the information indicates that on average 12 liters of pesticides are used per hectare of cultivated soybeans; 8 liters / ha in sugarcane; 6 liters / ha for maize; 28 liters / ha for cotton; in coffee 10 liters / ha; and rice, 10 liters / ha.

(5) Herbicides, for example, accounted for $45 \%$ of total pesticides marketed, while fungicides accounted for $14 \%$, insecticides for $12 \%$, and other categories of pesticides, $29 \%$ of the national market. 
and / or commodities, ${ }^{6}$ on average, the 100 billion liters $^{7}$ applied to crops, in 2016, represents an average of 487,80 liters for each Brazilian. Research results from previous and ongoing studies show how various insecticides (organophosphates, carbamates, organochlorines, pyrethroids), herbicides (dinitroferols, phenoxyacetic, dipyridyls) and fungicides (dithiocarbamates, fentalamides) are responsible for damaging human and environmental health and are catalysts for accidents and occupational diseases.

The cruelty and augmentation of injuries ${ }^{8}$ and acute and subacute intoxication (gastrointestinal, renal, dermal, hepatic, neurological, pulmonary, immunological deficiencies, clinical psychiatric) and chronic (psychiatric, neurological, endocrine, teratogenic, mutagenic and carcinogenic) intoxications, have direct repercussions on a wide range of pathogens, such as depression, deafness, Parkinson's, congenital malformation, diabetes, hypothyroidism, infertility, miscarriages, anencephaly and cancer. In the case of the sugarcane agroindustry, for example, we have found pathogens that in extreme cases lead to death and are simultaneously and directly or indirectly associated with: a) the types of occupational exposure of sugarcane workers; b) the presence of contaminant residues in the food eaten both by these workers in the workplace and the final consumers of food products from the sugar cane industry); c) environmental contamination (air, water, soil, rain, etc.), be it from the workplace, the sugarcane crop, or the communities surrounding the large areas of monoculture sugarcane exploitation, where the vast majority of these workers' families live. ${ }^{9}$

Our analysis and research effort is based on the central objectives of the ongoing research project "Mapping and Analysis of the Sugarcane Hydro-Agricultural Business in Pontal do Paranapanema-São Paulo-Brazil: Labor relations, conflicts and land and water use patterns, and environmental health", ${ }^{10}$ aimed at the intensive use and excessive proliferation of the application of agrochemicals in the sugarcane plantations of the region of Pontal do Paranapanema, in the interior of the state of São Paulo. Along the same lines, we extracted information and understanding from two other Research Projects, which are also part of the reflections based on the scope of the Research Project, in effect, 1) "Class Territorial Movement, Labor Plasticity and Health Impacts on the Worker in the Twenty-first Century (territorial conflicts and struggle for access to land and water)";11 and 2) "Territorial Expansion of the Hydro-Agricultural Business and the Impacts for Work and Social Movements in the Twenty-first Century". ${ }^{12}$ Likewise, research activities are included at the doctoral level, in various parts of the Brazilian territory, under our guidance. ${ }^{13}$

\section{FORMS OF SYSTEMIC DEGRADATION OF LABOR AND THE HEALTH-DISEASE RELATIONSHIP}

The regressivity that accompanies the spectral innovations in the degradation of labor attests to the systemic irrationality of the capitalist mode of production. The immanence of the extraction of more labor, from the pure and combined forms of relative and absolute surplus value, concretizes the objectivity of the times of exploitation / subordination and control of labor, as well as the modes of production, distribution and circulation of capital.

(6) It is enough to consider that, on average, throughout the vegetative cycle, approximately 12 liters / ha are used on sugar cane.

(7) For each liter of active ingredient, 100 liters of water will be added to produce the soup that will be effectively applied in the crops.

(8) Pignati (2013), proposes a reflection on the increasing of the harm to worker's health in the direct ratio of studies that deal with occupational health, aiming at not only the individual, but the whole collective of workers exposed to pathogens, directly linked to the environment remade by the productive restructuring of capital related to the new way of producing commodities.

(9) More details, see: Novaes, 2007.

(10) Thematic Project financed by FAPESP (Process: 2012 / 23959-9), effective from August 2013 to July 2018, under our coordination.

(11) Project funded by CNPq (PQ-1), Process: 304514 / 2015-2.

(12) Project funded by CNPq (Universal), Process: $458711 / 2014-4$.

(13) Research already completed: Oliveira (2009); Souza (2011); Bezerra (2012); Azevedo (2013); Alves (2014); Dourado (2015); Perpetua (2016). Ongoing: Barreto (2014-); Piñeros (2014-); França (2014-). 
The empirical identity of the technological transition underway in the sugarcane agribusiness in Pontal do Paranapanema, as part of the productive restructuring of capital, is expressed with strong features of the mechanization of cutting and planting - as new characteristic forms of disease - combined with the intensification of the chemical-dependent model of cultural dealings, which is the very existence of systemic degradation.

The line of reasoning that we establish associates the health-disease relationship with work processes, together with the nexuses that give rise to occupational diseases and, in concrete terms, identify exposure to risks - not to accidents, as mistakenly conveyed - reveals the very existence of the instruments of capital control over labor and society in general. (HECK, 2017). Thus, the work-health relationship is society itself responding to the forms of social control exercised by capital (THOMAZ JUNIOR, 2014a).

Also, the production of eucalyptus for cellulose, under the strict control of a few large corporations (Fibria Celulose, Suzano Pulp and Paper, Eldorado Brasil Celulose, Stora Enso, CMPC, Cenibra, Jari Celulose and Klabin), verifies that the spectral mechanization of the production process is not an impediment to workers' risks or exposure to risk (chemical, physical and biological). On the contrary, it helps to conceal them (PERPETUA, 2016). Several statements obtained in the field indicate that the "flexible" forms of organization and control of labor, based on the outsourcing of contracting, variable remuneration, dictated by unattainable and abusive production goals, and the expansion of the working day (extraction of absolute surplus value) or by the intensification of the work rhythm (extraction of relative surplus value) make up the substrate in which the harm swarms.

The irradiation of these processes challenges us to strip the relationship between the Brazilian development model, the impacts on labor and the consequences for agrarian reform policies, food and energy sovereignty, and collective and workers' health. In other words, our attention to the phenomenon of the systemic degradation of labor leads us to place it as one of the results of contemporary precariousness, evidenced by the risks and injuries to worker's health. However, these have been historically predicted in the mechanisms of exclusion and / or precarious inclusion of workers in the metabolic system.

The workers' demand for public policies aimed at Agrarian Reform and food production / commercialization brings to the fore the conscious commitment to the project to strengthen family and peasant agriculture (OLIVEIRA, 2016). The denial and combat of these workers' initiatives by the state, capital and the bourgeoisie, in general, add to the actions deliberately directed to the pure and / or combined wage forms and multiply the occurrence of the systemic degradation of labor. Through this understanding as an expression of the wide range of objective realizations / non-realizations, as part of the contradictory movement of the living totality of labor, we can situate the different forms of existence / re-vindications and the meanings of the subjectivities that mark the territories of the degradation of labor (HECK, 2017).

In an earlier moment (THOMAZ JUNIOR, 2014b) we have argued that the society of capital, surmounted on the contradictory environment of productive restructuring, has been intensively modified in the last decades, which has affected the class structure, the very dynamics of the objective and subjective dimensions of workers and the geographic dynamics of labor, as a continuous and contradictory movement of (dis) realization of territorialization / de-territorialization-re-territorialization. From these theoretical-methodological references, we can see the understanding of the universe of labor, increasingly fragmented, heterogenized and precarious, particularly under the crossfire of the productive restructuring of capital, yet without losing its centrality. In summary, we have a re-sizing of social configurations that support different expressions and meanings of labor, both in the countryside and in the cities, in order to add new values and meanings to the trade unions,${ }^{14}$ associations, and political parties, etc.

(14) Regarding the challenges in the field of trade unions, see: Sczip (2013). 
To these challenges is added the perverse synchronicity between the implosion of the productive forces and their imminent dismissal, transforming contingents of workers into junk. As a consequence, the fact that labor as a measure of wealth, already in its abstract form, passes through profound changes, but has not ceased to be a reference for value, for the law of value, for the accumulation of wealth (THOMAZ JUNIOR, 2014b). Moreover, in the twenty-first century, polyvalence and multifunctionality, very different from what prevailed in the Taylorist and Fordist companies, attest that the work process implemented by companies is born of its fissure.

The phase of "multifunctional desespecialization", "multifunctional work" and outsourcing expresses the intensification of rhythms, times and work processes, which are territorialized in the various instances, areas and sectors of labor activity, that is, both in the industrial world and services and the hydro-agricultural business (HECK, 2015). With regard to outsourcing, Druck (2011) states that it is one of the facets of the broader process of the precariousness of labor, manifested in the harm to workers' health, with repercussions beyond the working environment. The roots of this process, in the areas of recent expansion in the production of commodities, responds to the demands of the destructive development of productive forces, that is, the technological and managerial modernization that disrespects the prescribed health conditions uses the increase in productivity, the reduction of production costs and, with this, the lowering of wages and the elimination of the workforce. Full proof of the business strategies to extract the most value from the workers are the findings regarding injuries, accidents, mutilations, etc. Even though under reporting shows the lack of awareness of this reality, on a ratio of 50 to 1, based on the non-issue of CATs (Communication of Work Related Accidents) by companies, the fines imposed by the Labor Ministry (MPT) on the hydro-agricultural businesses also reveal the disregard by capital.

It is important to note that public intervention in workers' health has an important pillar for health promotion in the Unified Health System (SUS), which is linked to the Occupational Health Surveillance (VISAT), a product of the creation of the National Network for Integrated Care of Workers (RENAST) in 2002, which should be integrated with the Occupational Health Reference Centers (CEREST) - (GUIMARÃES, 2008). Despite the progress made in the scope of the SUS, these steps are still very timid, marking the degradation of labor with systemic signs, starting with diagnosis, including preventive supervision of risks and injuries and decision making for referrals by the health service.

At the global level, according to the International Labor Organization (ILO), on the basis of the information available for 2015, there were 6,300 work-related deaths per day, and 317 million workers were victims of accidents every day, which is equivalent to 850,000 daily injuries, with four days or more of leave. This includes "accidents" involving serious intoxication with pesticides, resulting from hydro-agricultural business activities. In Brazil, according to Rodrigues (2012), more than 400,000 cases of pesticide contamination are reported, however, unlike acute contamination, the diagnosis of chronic contamination is cumulative and symptoms may delay in appearing, as a rule being confused with common diseases and are not notified. According to a study by the Central Única dos Trabalhadores (CUT) (Apud REDE BRASIL ATUAL, 09/05/2014), in the last 42 years, 38 million work-related accidents have occurred in Brazil, of which 560,000 victims are identified as permanently incapacitated. Despite the fact that in the last two decades, the number of deaths at work has been decreasing gradually, the number of occupational accidents and illnesses (Table 1) has increased, in an expressive and worrying way, with the country occupying the shameful fourth place on a global level.

In this context, therefore, a new profile of work-related illnesses has taken the lead in Brazil, in decreasing order, diseases of the musculoskeletal system, lesions, poisonings and mental and behavioral disorders (DELGADO, 2012).

The link between work and health that we are making in our research allows us to understand the current meanings of the immanent degradation in the sugarcane hydro-agricultural business which we refer to as systemic. That is, this degradation covers both the social relations of labor and 
production and directly rebounds on the environment, impacting on environmental health, adding renewed elements that are imposed on the workers' demise.

Table 1 - Impact of Work on Workers' Health in Brazil (1990-2012)

\begin{tabular}{c|c|c|c}
\hline Period & Accidents & Illnesses & Death \\
\hline 1990 & 693,572 & 5,217 & 5,355 \\
\hline 1995 & 424,137 & 20,646 & 3,967 \\
\hline 2000 & 363,868 & 19,605 & 3,094 \\
\hline 2005 & 499,680 & 33,096 & 2,766 \\
\hline 2010 & 709,474 & 17,177 & 2,753 \\
\hline 2011 & 720,629 & 16,839 & 2,938 \\
\hline 2012 & 705,239 & 14,955 & 2,731 \\
\hline Totals & $\mathbf{4 , 1 1 6 , 5 9 9}$ & $\mathbf{1 2 7 , 5 3 5}$ & $\mathbf{2 3 , 6 0 4}$ \\
\hline
\end{tabular}

Source: CUT, Org. Rede Brasil Atual (09/05/2014).

In essence, the interfaces between territorial dynamics, forms of domination and labor relations, forms of land use, water management and environmental health occupy a central place in the analysis of the consequences of the economic development model integrated to the dynamics of capital appreciation. After all, the processes of falling ill and dying are similar or different, regardless of whether workers live in one municipality or another. It is possible to extrapolate boundaries between states, as occurs in São Paulo and other states, in the context of the Polygon of the Hydro-agricultural business (THOMAZ JUNIOR, 2010, 2014).

Thus, the genesis and development of many diseases have a connection with labor (occupational) and underlying social relations (LOURENÇO, 2013), although there is a tendency in the health and social security services, mediated by the capitalist ideology, that identifies these manifestations in an a-historical way, as if falling ill and dying before one's time had no connection with the material and subjective reality of labor.

From this we extract that to abstract diseases as being linked only to human subjectivity, or even an accident, as a cause of self-will - as if the worker could premeditate them - is a simplistic and unreal analysis, which disregards the social relations of labor and of production surmounted in the social / metabolic structure of capital, its reproduction through the exploitation of labor and the capture of surplus value, and therefore structural characteristics of the systemic degradation. In short, it is not only the danger of environments and working conditions, but also of the labor relations that control and subject workers to different forms / intensities of barbarism, not only accidents and injuries and their consequences, but also being discarded, restrictions of freedom and autonomy, "[...] determinants in the process of life / health." (LOURENÇO, 2013).

\section{DEGRADED ENVIRONMENTS AND RESISTANCE TO LABOR}

When we propose to identify the different forms that express resistance to capital, although no longer restricted to the parameters of the traditional wage-earner or the Taylorist / Fordist worker, we extend our attention to other forms of labor explication, not only limited to the "factory floor", which, together, grow across all geographic scales and in magnitude. With regard to sociabilities that are not restricted to the essentially capitalist grid of relationships, we can take the examples of socio-cultural practices which directly involve communities in the memory of the land, that is, land seen not as a commodity but as a territory of life and existence, which means that by losing it, the possibility of existence is also lost. 
Identifying the territorial marks of labor and the dynamics that express the contradictory movement of different forms of realization / derealization, a task that we assume, in the Geography of labor, presupposes understanding the territory in its multi-scale / multi-dimensionality (THOMAZ JUNIOR, 2011). The experiences will allow us to reflect on reality, through labor, instead of "hiding" ourselves and protecting ourselves behind statements unrelated to the political praxis with which workers and social movements are building and requalifying the Geography of labor on the planet. It is an understanding of the different experiences of resistance, organization and plasticity of labor (THOMAZ JUNIOR, 2013b) that has been constantly remade, from the territorial class movement (THOMAZ JUNIOR, 2012), the attempts at an organic unification of struggles (THOMAZ JUNIOR, 2004), which will enable us to know the rootedness and the emancipatory and revolutionary sense of labor, not the preconceived definitions, forged and distant from the centrality of the class conflict and the social process that sustains it.

The sense we give to the concept of degradation of labor is born in some way from the loss of the ontological dimension of labor producing "things" useful for the hierarchical imposition of labor under the domination of others, for the production of exchange values. Therefore, it is important to show that the concept of degradation of labor is related to a historical process that has reduced labor (the foundational category of the social being and eternal necessity of the world of men) to a mere salable commodity. It is this historical condition that is the foundation of the second-order mediations (MÉSZÁROS, 2002), which underlie the degradation of labor.

In this way, the degradation of labor, associated to the physical and mental illnesses of the workers in the hydro-agricultural business, reveals that occupational diseases are less related to biological predispositions and organic abnormalities, which have an isolated incidence in workers, than, fundamentally, with the organization and performance of work activities. That is, under certain conditions in contemporary societies, which aim for flexibility and the intensification of the exploratory processes, linked to the noncompliance with labor legislation, the degradation of labor is further accentuated.

Perceiving accidents and occupational diseases less as linked to univocal factors and more to social process (social determination of diseases) helps us to understand that the imposition of exploitation, subordination, violence, noncompliance with legal codes and the truculence of capital occupy a prominent role in determining labor relations, with broad implications for workers' health. This perspective, which makes it possible to apprehend the health-work-disease process in its collective dimension, based on historical and geographical determination, foresees the social determination of the relationships and processes of domination and labor control by capital; in the case of agricultural activities it is based on the understanding of the concept of the extended rural accident (PIGNATI; MACHADO, 2007). Thus, the territory of the externalization of these relationships is essential in understanding the foundation of the subjugation of labor to the process of adding value / reproduction of capital in class society. As Pignati (2013) states, “[...] workers' health surveillance actions should look at the origins of hazards, not just health hazards and environmental damage."

\section{CURRENT MEANINGS OF HEALTH IN THE HYDRO-AGRICULTURAL BUSINESS}

In this sense, understanding the health-illness pair together with the category of labor implies attuning it to the totality of the social process of labor (production and reproduction of life) and to the set of social relationships that men and women establish among themselves as historical subjects (THOMAZ JUNIOR, 2011). In this way, injuries to workers' health cannot be naturalized, nor can they be attributed to chance or accident. Thus, occupational accidents / diseases are more associated with societal metabolism than with "unsafe acts". In fact, this approach can lead to individualized understandings of workers' health, to the point of relating accidents and occupational diseases to individual issues (HECK; THOMAZ JUNIOR, 2012). As Donnangelo and Pereira (1976) point out, 
studies on occupational health or the branch of medicine dedicated to this subject must be opened up to think about social space, and this is, therefore, crucial to the understanding of exposure to risk. This inspires us to think that work-related sickness and accidents must be perceived as part of a complex process of social plots rooted in the systemic irrationality of capital and that underlie the whole system of exploitation and degradation of labor (THOMAZ JUNIOR, 2011; 2014). This fact becomes clear when we observe that even official data from the statistical yearbooks of the Ministry of Social Security - which, as already pointed out, suffer from chronic underreporting - indicate the persistence and even increases in the total number of work related injuries in recent years. ${ }^{15}$

It is necessary to go further and consider work sickness from the perspective of the insane contradictions of contemporary bourgeois society (ALVES, 2013). The health problems of workers represent one of the most significant expressions of the systemic antagonism between capital and labor. That is, they reveal the unreformable nature of the society of capital based on the extraction of unpaid labor, a strange social relationship (MÉSZÁROS, 2007).

This is why the evident link between the expansion of commodities with the availability of land and water resources has been essential for capital strategies. Therefore, the ownership of land and water leads us to reflect on the role of the state in the empowerment of capital and its effects on the social context of exclusion and hunger, underlining the need for the emergence of agrarian reform and food sovereignty.

It is precisely in this environment of wealth appropriation that land and water occupy a central place when the survival of the planet, food production, exploitation and commercialization of raw materials are called into question. In this first decade of the twenty-first century, new and meaningful elements in disputes around land and water or access to these goods in the world, and particularly in Brazil, are strikingly important.

The labor movement, the nature movement and the health movement gain analytical importance, because we understand that another relationship between society and nature can be built within territorial and class disputes, under the assumption of pointing to development alternatives aimed at the sustainable development of society and nature.

Thus, the diseases associated with the recent transformations of the expansion of capitalism, whether in the countryside, through monocultures, intoxications through applications of heavy pesticide loads, loss of biodiversity, production gains, etc., or in cities, are surprising, with all the aggravating factors that affect the painfulness and the unprotected work environment against the contaminants, production gains, sub-contracting etc. (PIGNATI, 2013).

This situation is even more ominous than assumed with the entrance to the stage of Law 3,200, of 2015, which is being negotiated in the National Congress and is already in the voting phase. In fact, it is what is lacking for the integral control of the large agricultural-chemical-food-financial transnational conglomerates, secured by the political alliance of the National Congress and the coup government, of the production, commercialization, experimentation, transportation, final disposal of waste, etc. of pesticides. Other projects with the same intentions are synthesized in Bill 3,200, however, the pro rata interests of capital are ensured by the withdrawal of chemical inputs from the attributes of agrochemicals, through the imposition of a new denomination: defensive phytosanitary products and environmental control products. The ruses of the PL 3,200 find a comfortable place in the polluted environment of the coup-supporting congressmen, who, synthesizing more than 50 projects going through the National Congress, since 2005, guarantee diverse interests, such as loopholes in the current legislation, especially regarding the flexibility lobbied for by the polluters, who will have at their disposal a new regulation, more permissive of the production and commercialization (including import and export) of pesticides.

(15) The number of accidents (typical and en route) and cases of occupational diseases, with or without registered CAT, totaled 659,523 cases in 2007 , rising to 717,911 cases in 2013 ; an increase of $8.8 \%$ (58,388 cases). 


\section{FINAL CONSIDERATIONS}

We must link the main problems that are externalized in the field of public health to environmental degradation by pesticides. This is an expression of a model of society and development, in this case, for the countryside, based on business agriculture, large land areas and monocultures aimed primarily at the external, technological and chemical-dependent market. Moreover, agrochemicals should not be conceived only as something that can be controlled, but as an imminent risk, part of the logic of the model of a society that needs to be understood and evaluated by society itself. In fact, the adoption of the chemification of agricultural processes (post-planting, culture treatments and preparation) in the face of constant exposure to risk, contamination, intoxication, serious accidents, discarding and even death, is one of the topics that surpass the specific demarcations of worker's health and reach the dynamics of society in general, or of collective health. Therefore, this labor reality is territorialized in the marks of the systemic vulnerabilities of the society of capital, in the environment of territorial conflicts, the expropriations of peasants and native populations, the destruction of native vegetation, etc.

Faced with this, it is necessary to guide this new pattern of destructive social development. That is, the objectives are to neutralize resistance and to break the links in the forms of land use from the food producing circuit. At the center of capital's objectives are the secured class interests, that is, land ownership and / or control over land, taking into consideration expressive portions of devolved areas linked to the productive and speculative circuit, preventing millions of workers and their families from establishing rural settlements, or in the cases of squatters, even getting land regularization and access to land and water to establish roots and produce food. This expressive working population that continues to be excluded and / or experiences precarious and temporary insertion in the labor market, who are sometimes found in camps along roadsides, could be added to those already in charge of producing food. However, due to the absence of regular public policies aimed at the acquisition of equipment, inputs, costing, commercialization (DELGADO, 2012) etc., although they account for significant portions of food production in Brazil, they also account for a significant portion of the nutritional risk as a consequence of levels of impoverishment, abandonment and exclusion. (LEAL, 2017).

Thus, by linking risks, harm, illnesses, accidents and other occurrences, in the context of the systemic degradation of labor, the territorial dynamics of society and the contradictions of the labor process in the hydro-agricultural business, we are reinstating a new format to discuss the health-disease relationship of workers involved in the hydro-agricultural business and society in general, because the title of champion of chemical contamination is amplified, as the ownership of consumption of pesticides, protagonized by capital, in the countryside, in Brazil, brings with it the immediate consequence of loss of quality of life and work, water sources, soil, air, animals, food crops, as well as sickness and health of workers and society as a whole.

Therefore, there is a need to think of radical alternatives or those that have another historical horizon, beyond capitalism and the corporate metabolism of capital, or the logic of profit, accumulation, reproduction of inequalities and immanent destructiveness.

These considerations bring us closer to the expectations we put forward in this article, that is, labor in the degraded environment of the hydro-agricultural business in Brazil can only be overcome if it is considered a radical rupture of the sociometabolism of capital.

For the workers still present, in a residual manner, in the manual cutting and planting of sugarcane, or for those who were incorporated into the mechanization process, as well as the other raw materials included in the commoditization of agricultural and livestock and who today perform functions related to the conduction / operation of machinery, work accidents and the chances of becoming ill as an undeniable reality in these work environments. Production goals and activities that are almost impossible to achieve, psychological pressure and bullying unleash stress and psychic imbalance, implying problems related to the worker's physical and mental health. 
This expansionism of the sugarcane hydro-agricultural business, associated with the destructive development of productive forces, has as an exponent and strategy, for the optimization of production and profits, the mechanization of agricultural operations, especially cutting and planting, related, therefore, to the intensification of utilization of agrochemicals (pesticides and fertilizers). (BARRETO, 2012). For the workers, this technological transition does not go unnoticed: on the contrary, they are the ones most affected by it, because of their way of being and insertion in work, their employment bond, form of payment, routine and exploitation at work, and health and forms of organization / representation, are more than ever put to the test. As we discussed in section 2, this is the case of independent workers, who grow in numbers and who do not have support, or even closeness to organizations.

The revelation of this expedient and labor reality occupies our research, as well as the other researchers linked to the Thematic Project / FAPESP. However, although we still have initial information, it is safe to say that we are facing a new frontier of labor degradation, which makes it even more sustained and identified as systemic, with predictable repercussions for workers' physical and mental health. Any similarity to the control systems inaugurated by the productive restructuring of capital, in the manufacturing plants, in the service sector, and so on, is not merely a coincidence. New systematic production goals, less involvement and / or prohibition of participation of political representation entities such as unions, greater control over workers, etc. are consolidated as routine expedients in the life inside and outside the labor of workers involved in the agricultural activities of sugar cane, eucalyptus, soybeans, the mainstay of capitalist modernity in the countryside.

The organizational and productive (re)arrangements imposed by productive restructuring, the neoliberal package and the option made by capital based on the hydro-agricultural business, especially in commodities (agrochemicals, fertilizers and other substances that are hostile to human health), are events / processes / tactics of capital that will contribute to intensify the already precarious working conditions. These, therefore, are multiplied by the long working days, noncompliance with contracts, collective agreements and other protective acts, formatting systemic degradation as a central characteristic of the perverse modernity of the hydro-agricultural business in Brazil.

The understanding of this societal process stimulates us to reiterate the radical rupture with the praxis that builds the destructive development of the capitalist productive forces, in capturing the subjectivity of the generic being of man as a social being, and the need to continue betting on the transformation of our conditions of existence beyond life reduced to a strange work time, but seeking to restore to it the dimension of vital activity, as an ontological content, through the privileging of the centrality of labor as a reference of the emancipatory and class struggle. Hence, to gamble on the activity of labor endowed with meaning and marked by substantive equality between autonomous and free subjects of class domination. However, it is in the midst of this contradictory dimension that, at the same time that it emancipates, it alienates, as it humanizes, it degrades, liberates and enslaves, making our studies of society through labor essential to decipher forms of control, domination, resistance and emancipation of labor. A subject already discussed in previous texts, here I return to the dimension of the coexistence between the positivity and the negativity of labor in order to emphasize the contradictions that permeate humanity immersed in the sociometabolism of capital (THOMAZ JUNIOR, 2009; 2011; 2015), the work of producing things would mean to hypostasize it for the present and for the future. On the contrary, with the focus on insisting on the limitation of the concept of working class fixed to the identity of the manual worker, wage earner and producer of surplus value. But even the broader understanding of all wage-earners (productive and unproductive) does not contemplate the increasingly expressive contingents of men and women who do not fit these assumptions, standing on the fringes of supreme exclusion. We refer to the unemployed, without work, without profession, without a house, without land, without prospects, the hungry who grow at the speed of light and who live in the orbit of the hydro-agricultural business, such as, for example, the independent workers. The object of our studies, but for another 
time in our systematizations, already represents expressive contingents of the horde of non-resident day-laborers who wander daily through the street corners in search of daily work. However, more disenfranchised and poorly remunerated than the agricultural laborers, who have the luxury of having a signed work permit and bond, the independent ones are on the margins of the already degraded working conditions and are objects of the contemporary systemic degradation.

\section{ACKNOWLEDGMENTS}

This text is a product of research activities carried out under two Research Projects, funded by CNPq: 1) "Territorial Expansion of the Hydro-agricultural business and the Impacts for Work and Social Movements in the Twenty-First Century." Call: UNIVERSAL (Case: 458711 / 2014-4). 2) "Class Territorial Movement, Labor Plasticity and the Impacts on Workers' Health in the Twenty-First Century (territorial conflicts and the struggle for access to land and water)". Call: PQ-1/CNPq (Process: 304514 / 2015-2), and of a Project, financed by FAPESP: 3) "Mapping and analysis of the territory of the sugarcane Hydro-agricultural business in Pontal do Paranapanema-São Paulo-Brazil: Labor relations, Conflicts, forms of land and water use, and environmental health. " Thematic Project / FAPESP (Process: 2012 / 23959-9). Duration: 08/01/2013 to 07/31/2018.

\section{BIBLIOGRAPHICAL REFERENCE}

ALVES, G. Prefácio: o adoecimento do trabalho como falha metabólica do capital. In: NAVARRO, V. L.; LOURENÇO, E. A. de S. (Org.). O Avesso do Trabalho III: saúde do trabalhador e questões contemporâneas. São Paulo: Outras Expressões, 2013.

ALVES, J. A revolta de Jirau: a degradação do trabalho represada na produção de energia elétrica na Amazônia. Tese (Doutorado em Geografia) - PPG/Geografia/FCT/UNESP. Presidente Prudente, 2014.

ANTUNES, R. Os sentidos do trabalho. São Paulo: Boitempo, 1999.

ANTUNES, R. Século XXI: nova era da precarização estrutural do trabalho" In: ANTUNES R.; BRAGA, R. Infoproletários - degradação real do trabalho virtual. São Paulo: Boitempo, 2009. p.231-238.

ANTUNES, R.. Las deconstrucciones del trabajo, su nueva morfología y la era de las rebeliones. Revista Izquierda, v. 1, 2013, p. 4-56.

ANTUNES, R. Desenhando a nova morfologia do trabalho no Brasil. Estudos Avançados, v. 28, n. 81, 2014.

ANTUNES, R. La era de las rebeliones, de las contrarrevoluciones y del nuevo estado de excepción. Herramienta (Buenos Aires), v. 1, p. 69-78, 2016.

AZEVEDO, J. R. N. As ações do agrohidronegócio e as formas de controle do trabalho no Mato Grosso do Sul. Tese (Doutorado em Geografia) - PPG/Geografia/FCT/UNESP. Presidente Prudente, 2013.

BARRETO, M. J. Territorialização das agroindústrias canavieiras no Pontal do Paranapanema e os desdobramentos para o trabalho. 2012. 244 f. Dissertação (Mestrado em Geografia) - Faculdade de Ciências e Tecnologia, Universidade Estadual Paulista, Presidente Prudente, 2012.

BEZERRA, J. E. Dinâmica geográfica do trabalho e da luta pela terra no território do agronegócio da fruticultura no Nordeste. Tese (Doutorado em Geografia). PPG/Geografia/FCT/UNESP. Presidente Prudente, 2012.

BIHR, A. Da grande noite à alternativa. São Paulo: Boitempo, 1998.

BOITO JUNIOR, A. A burguesia brasileira no golpe do impeachment. Brasil de Fato, 06 janeiro, 2017. Disponível em: www.brasildefato.com.br. Acesso em: 19 de fevereiro de 2017.

BOMBARDI, L. M. Intoxicação e morte por agrotóxicos no Brasil: a nova versão do capitalismo oligopolizado. Boletim DATALUTA - Artigo do mês: set. 2011.

CARneIRO, F. F.; AUGUSTO, L. G. da S.; RIGOTTO, R. M.; FRIEDRICH, K.; BÚRIGO, A. C. Dossiê ABRASCO: um alerta sobre os impactos dos agrotóxicos na saúde. Rio de Janeiro: EPSJ/São Paulo: Ex- 
pressão Popular, 2015.

CASTILHO, I. Intoxicações por agrotóxico quadruplicam no Sudeste: donas de casa estão entre principais vítimas. De olho nos ruralistas, 31/10/2016. Disponível em: http://outraspalavras.net/deolhonosruralistas. Acesso em: 12 abr. 2017.

CHESNAIS, F. Não só uma crise econômica e financeira, uma crise de civilização. In: NOBILE, R.; JUNKINGS, I. (Org.). István Mészáros e os desafios do tempo histórico. São Paulo: Boitempo, 2011. p.187-198. DELGADO, G. Do capital financeiro na agricultura à economia do agronegócio: mudanças cíclicas em meio século. Porto Alegre: EdUFRGS, 2012.

DEJOURS, C. A loucura do trabalho: estudo de psicopatologia do trabalho. São Paulo, Cortez-Oboré, 2015. DONNANGELO, M. C.; PEREIRA, L. Saúde e sociedade. São Paulo: duas cidades-Martins fontes, 1976. DOURADO, J. A. L. Das terras do sem-fim aos territórios do agrohidronegócio: conflitos por terra e água no Vale do São Francisco (BA). Tese (Doutorado em Geografia) - PPG/Geografia/FCT/UNESP. Presidente Prudente, 2015.

DRUCK, M. G. Trabalho, precarização e resistências: novos e velhos desafios? Cad. CRH, Salvador, v. 24, n. 1, 2011.

GUIMARÃES, R. B. Regionalização da saúde no Brasil: da escala do corpo à escala da nação. 2008. Tese (Livre-Docência) - Departamento de Saúde Ambiental, Faculdade de Saúde Pública/USP, São Paulo, 2008.

HARVEY, D. O novo imperialismo. São Paulo: Loyola, 2013.

HECK, F. M. Trabalho precário e terceirização na cadeia avícola do Oeste Paranaense. Tempos históricos, vol. 19, n. 2, p. 92-110, $2^{\circ}$ Sem. 2015.

HECK, F. M. No abate de frangos e suínos: o descarte do trabalho. Curitiba: Prismas, 2017.

HECK, F. M.; THOMAZ JUNIOR, A. Territórios da degradação do trabalho: os impactos na saúde e na vida dos trabalhadores de frigoríficos de aves e suínos no Brasil. In: SEMINÁRIO DE SAÚDE DO TRABALHADOR DE FRANCA, 8., 2012, Franca. Proceedings online... UNESP Franca, Disponível em: <http:// www.proceedings.scielo.br/scielo.php?script=sci_arttext\&pid=MSC0000000112012000100014\&lng=en\& nrm=abn>. Acesso em: 21 fev. 2013.

HUWS, U. The making a cybertariat: virtual work in a real world. London: Merlin, 2004.

JONES, W, prólogo. In: LAULLÓN, R. R.; SÁNCHEZ, A. T. La classe obrera no va al paraíso. Madrid: Ediciones Akal, 2016.

LEAL, S. C. T. A Dinâmica Territorial do Programa de Aquisição de Alimentos (PAA), no Pontal do Paranapanema-SP e os Conflitos com o Agohidronegócio Canavieiro. Dissertação (Mestrado em Geografia). PPG/Geografia/FCT/UNESP. Presidente Prudente, 2017.

LOURENÇO, E. A. S. Alienação e Agravos à saúde dos Trabalhadores no Setor Sucroenergético. In: LOURENÇO, E. A. S.; NAVARRO, V. L. (Org.). O Avesso do Trabalho III: Saúde do Trabalhador e Questões Contemporâneas. Outras Expressões- SP, 2013.

LUXEMBURGO, R. A acumulação do capital: estudo sobre a interpretação econômica do Imperialismo. Rio de Janeiro: Zahar Editores, [1913] 1970.

MARINI, R. M. Dialéctica de la dependencia (1973). En publicación: América Latina, dependencia y globalización. Fundamentos conceptuales Ruy Mauro Marini. Antología y presentación Carlos Eduardo Martins. Bogotá: Siglo del Hombre - CLACSO, 2008. ISBN 978-958-665-109-7

MENDONÇA, M. R.; MESQUITA, H. A. O agrohidronegócio no cerrado goiano: a construção das (re)existências. In: ENCUENTRO LATINOAMERICANO CIENCIAS SOCIALES Y REPRESAS, 1; ENCONTRO BRASILEIRO DE CIÊNCIAS SOCIAIS E BARRAGENS, 2. Anais... Salvador, 2007.

MÉSZÁROS, I. Para além do capital. São Paulo: Boitempo, 2002.

MÉSZÁROS, I. O desafio e o fardo do tempo histórico. São Paulo: Boitempo, 2007.

MÉSZÁROS, I. Estrutura social e formas de consciência II. São Paulo: Boitempo, 2011.

MÉSZÁROS, I. A montanha que devemos conquistar. São Paulo: Boitempo, 2015.

NOVAES, J. R. Impressões: Uma reflexão sobre o trabalho no agronegócio da cana. Uma síntese do Encon- 
tro "Trabalhadores Canavieiros: Saúde, Direito, Trabalho". São Carlos, 2007. Disponível em: http://www. pastoraldomigrante.com.br Acesso em: 08 jun. 2008.

OLIVEIRA, A. M. S. de Reordenamento territorial e produtivo do agronegócio canavieiro no Brasil e os desdobramentos para o trabalho. Tese (Doutorado em Geografia). PPG-Geografia/FCT/UNESP. Presidente Prudente, 2009.

OLIVEIRA, A. U. A mundialização da agricultura brasileira. São Paulo: Iãnde Editorial, 2016.

PERPETUA, G. M. Pilhagem territorial, precarização do trabalho e degradação do sujeito que trabalha: a territorialização do capital arbóreo-celulósico no Brasil contemporâneo. 2016. 370f. Tese (Doutorado em Geografia) - FCT/UNESP - Campus de Presidente Prudente, Presidente Prudente, 2016.

PERPETUA, G. M.; THOMAZ JUNIOR, A. A verdadeira natureza do trabalho nos novos territórios da celulose. In: SEMINÁRIO DE SAÚDE DO TRABALHADOR, IX. Anais... Franca, set. 2015.

PIGNATI, W. A. O processo Saúde-Trabalho-Doença, os Sindicatos e os Desafios Para Vigilância em Saúde do Trabalhador. In: LOURENÇO, E. A. S.; NAVARRO, V. L. (Org.). O Avesso do Trabalho III: Saúde do Trabalhador e Questões Contemporâneas. Outras Expressões- SP, 2013.

PIGNATI, W. A.; MACHADO, J. M. H.; CABRAL, J. F. Acidente rural ampliado: o caso das "chuvas" de agrotóxicos sobre a cidade de Lucas do Rio Verde - MT. Ciência \& Saúde Coletiva, v. 12, n. 1, p. 1005114, 2007.

REDE BRASILATUAL. 09/05/2014. Especialistas alertam para extensão social dos danos do trabalho. Disponível em: $<$ http://www.dmtemdebate.com.br/abre_noticia.php?id=796> (Acesso em 14/10/2014).

RIBEIRO, H. P. De que adoecem e morrem os trabalhadores na era dos monopólios. São Paulo: Sem Editora, 2015.

RIGOTTO, R. M. et al. Agrotóxicos, trabalho e saúde: vulnerabilidade e resistência no contexto da modernização agrícola no Baixo Jaguaribe/CE. 1. ed. Fortaleza: Edições UFC, 2011.

RODRIGUES, C. L. Agrotóxicos: saúde e segurança dos trabalhadores rurais, aspectos preventivos e controle de riscos, perspectivas jurídicas e extrajurídicas. 2012. 137f. Monografia (Especialização em Direito Material e Processual do Trabalho), Universidade de São Paulo (USP).

ROMERO, R. L.; TIRADO, A. S. La classe obrera no va al paraíso. Madrid: Ediciones Akal, 2016.

SCZIP, R. R. Sindicato de Estado no Brasil e os limite da ordem. In: LOURENÇO, E. A. S; NAVARRO, V. L. (Orgs.). O avesso do trabalho III. 1.ed.São Paulo: Outras Expressões, 2013.

SILVA, M. A. M. O trabalho oculto nos canaviais Paulistas. Agrária, São Paulo, n. 2, p.2-39, 2005.

SILVA, M. A. M. A morte ronda os canaviais Paulistas. Revista Abra, v. 3, n. 2, p. 11-43, ago./dez. 2006.

SMITH, N. Desenvolvimento desigual. Rio de Janeiro:Bertrand, 1988.

SOUZA, S. M. R. A emergência do discurso do agronegócio e a expansão da atividade canavieira: estratégias discursivas para a ação do capital no campo. Tese (Doutorado em Geografia). PPG-Geografia/ FCT/UNESP. Presidente Prudente, 2011.

THOMAZ JUNIOR, A. A (des)ordem societal e territorial do trabalho. (Os limites para a unificação orgânica). In: MARQUES, M. I.; OLIVEIRA, A. U. (Org.). O campo no século XXI: território de vida, de luta e de construção da justiça social. São Paulo: Casa Amarela/Paz e Terra. São Paulo: Laboratório de Geografia Rural, 2004. p.71-85.

THOMAZ JUNIOR, A. Não há nada de novo sob o sol num mundo de heróis! (A civilização da barbárie na agroindústria canavieira). Revista Pegada, Presidente Prudente, v. 8, p. 5-25, 2007.

THOMAZ JUNIOR, A. Dinâmica geográfica do trabalho no século XXI. (Limites explicativos, autocrítica e desafios teóricos).2009. 997p. Tese (Livre Docência) - Faculdade de Ciências e Tecnologia, Universidade Estadual Paulista, Presidente Prudente, 2009.

THOMAZ JUNIOR, A. O agrohidronegócio no centro das disputas territoriais e de classe no Brasil do Século XXI. Campo Território, Uberlândia, v. 5, n. 10, p. 21-38, 2010.

THOMAZ JUNIOR, A. Intemperismo do trabalho e as disputas territoriais contemporâneas. Revista da ANPEGE, Campinas, v. 7, n. 1, n. esp., p. 307-329, out. 2011.

THOMAZ JUNIOR, A. Degradação e Centralidade do Trabalho (As Contradições da Relação Capital x Tra- 
balho e o Movimento Territorial de Classe). Revista Pegada, Presidente Prudente, v. 12, n. 2, p. 4-19, 2012. THOMAZ JUNIOR, A. A Nova Face do Conflito pela Posse da Terra no Pontal do Paranapanema (SP): Estratégia de Classe do Latifúndio e do Capital Agroindustrial Canavieiro. In: ANTUNES, R. (Org.). Riqueza e Miséria do Trabalho no Brasil. v. 2. São Paulo: Boitempo, 2013a. p. 325-340.

THOMAZ JUNIOR, A. Emergências Teóricas do Movimento Despercebido/Negado da Plasticidade do Trabalho. In: LOURENÇO, E. A. S.; NAVARRO, V. L. (Org.). O Avesso do Trabalho III: Saúde do Trabalhador e Questões Contemporâneas. Outras Expressões- SP, 2013b. p. 125-142.

THOMAZ JUNIOR, A. O Tecido Social do Trabalho, a Produção de Alimentos x Agrohidronegócio e a Luta de Classes num Ambiente de Embates e Debates. In: O Avesso do Trabalho III. NAVARRO, V. L.; LOURENÇO, E. A. S. (Orgs.). São Paulo: Expressão Popular, 2013c. (ISBN: 978-85-64421-41-7). pp.29-60.

THOMAZ JUNIOR, A. Trabalho e saúde no ambiente destrutivo do agrohidronegócio canavieiro no Pontal do Paranapanema (SP) - Brasil. Revista Pegada, Presidente Prudente, v. 15, n. 2, p.4-18, 2014a.

THOMAZ JUNIOR, A. Movimiento territorial del trabajo en el campo y de la clase trabajadora. In: HIDALGO, F.; HOUTART, F.; LIZÁRRAGA, C. P. (Org.). Agriculturas campesinas en Latinoamérica Propuestas y Desafíos. Quito: CLACSO/IAEN, 2014b. p. 181-198.

THOMAZ JUNIOR, A. O trabalho como elemento fundante para a compreensão do campo no Brasil. In: NOVAES, H.; MAZIN, A. D.; SANTOS, L. (Org.). Questão agrária, cooperação e agroecologia. (Parte 4 Mundialização, trabalho, gênero e juventude do Campo). São Paulo: Outras Expressões, 2015. p.323-340. THOMAZ JUNIOR, A.; LEAL, A. C.; GUIMARÃES, R. B.; LUCHIARI, A. Conflitos Territoriais, Relações de Trabalho e Saúde Ambiental no Agrohidronegócio Canavieiro no Pontal do Paranapanema (SP). Scripta Nova - Revista Electrónica de Geografía y Ciencias Sociales, Universidad de Barcelona, v. XVI, n. 418 (30), nov. 2012. Depósito Legal: B. 21.741-98 [Nueva serie de Geo Crítica. ISSN: 1138-9788. Cuadernos Críticos de Geografía Humana]. Disponível em: http://www.ub.edu/geocrit/sn/sn-418/sn-418.htm. Acesso em: 14/03/2015

THOMAZ JUNIOR, A.; LEÃO, L. H. C.; PIGNATI, W. A. Trabalho Rural, Degradação Ambiental e Contaminação por Agrotóxicos. In: Avesso do Trabalho IV, São Paulo: Expressão Popular, 2016.

VERÇOZA, L.; SILVA, M. A. M. Cana, labor e adoecimento: a afirmação do nexo causal como uma forma de resistência. São Carlos, 2016. (Mimeogr.). 